\title{
Normative-legal principles of historical and local lore work institutions of extracurricular education of Ukraine (second half of the XX - beginning of the XXI century)
}

\author{
I. V. Parkhomenko
}

\author{
Sumy State Pedagogical University named after. A.S. Makarenko (Sumy, Ukraine) \\ Corresponding author. E-mail: parkhomenkoiv@ukr.net
}

Paper received 25.04.19; Accepted for publication 08.05.19.

\author{
https://doi.org/10.31174/SEND-PP2019-197VII79-12
}

\begin{abstract}
The article deals with the issue of formation and improvement of the normative and legal base of historical local lore studies of institutions of extracurricular education of Ukraine from the second half of the XXth century to the beginning of the XXI century in the context of four stages determined by the author. The normative and legal documents that outline the peculiarities of the formation, development and transformation of the out-of-school education system of the Ukrainian SSR and independent Ukraine are analyzed.
\end{abstract}

Keywords: normative-legal base, historical and local lore work, institutions of extracurricular education, tourist-local lore direction.

Introduction. The process of creation, formation, reformation of the normative and legal base of the system of out-of-school education, which lasts for about a hundred years, is defined by certain stages, attempts to create new, perspective perspectives, concepts and destroy old dogmas and stereotypes. This process is ambiguous, full of contradictions, and, in the time of modern reformation of the educational system of Ukraine, requires deep analysis and research.

Analysis of the last researches and publications. The theoretical foundations of the normative-legal framework of the activity of institutions of extracurricular education are reflected in the writings of such modern scholars and practitioners as V. Berek, A. Gutsol, N. Davidyuk, M. Kosilo, V. Marinych, R. Naumenko, N. Perepelytsya , V. Redina, S. Semoma, L. Tikhenko and others like that.

Thus, in particular, in the dissertation works V. Berek and A. Gutsol investigate the normative and legal regulation of the activities of institutions of extracurricular education Ukrainian SSR and independent Ukraine.

The purpose of the article is to analyze the legal and regulatory framework of historical and local lore work with children in institutions of extracurricular education in the second half of the twentieth century - the beginning of the XXI century.

This period covers the existence of a system of out-ofschool education in the two states (Ukrainian SSR and Ukraine). We consider a comparative comparison of these two systems, the comparison of specific features, the emphasis on contradictions and disadvantages. The historical and local lore work with children is one of the priority tasks for institutions of extracurricular education of tourist-local lore direction, therefore, first of all, in this exploration, we analyze the legal and regulatory principles of such institutions.

The article uses theoretical methods of research (analysis of scientific sources on the problem, synthesis, generalization and comparison).

Results and discussion. Analysis of the regulatory base of institutions of extracurricular education of the tourist-local lore direction of the second half of the XXth - beginning of the XXI century. We will carry out according to the four stages of formation and development of the system of out-of-school education: the first stage (1952-1973), the revival and development of the system of out-of-school education; the second stage (1973-1991), from the systematization and streamlining of the system of out-of-school education to its stagnation and de-ideologization; the third stage (1991-2000), the reformation of the system of out-of-school education, the clearance from Soviet dogmas and principles; fourth stage (2000-2017), updating the system of out-of-school education, bringing it in accordance with the world standards of education.

The first stage (1952-1973) covers the post-war period of the restoration of the system of public education of the UkSSR, the times of the Khrushchev thaw, the liberalization of public life, the humanitarian sphere, and the beginning of «stagnation», the centralization of all spheres of life. This stage was determined not only by the restoration of industrial and industrial capacity of the Ukrainian SSR after the Second World War, but also by the revival of the system of out-of-school education and the proclamation of the course for its rapid development, the promotion of extracurricular education as an alternative to «school education».

50th years of the twentieth century is characterized by special attention of public education bodies to rationalization of the network of institutions of extracurricular education, improvement of the regulatory framework aimed at creating favorable conditions for their activities. So, if in the USSR up to 1952, from 35 to 60 institutions of extracurricular education were created per year, then only in 1953170 establishments were opened. [2, p. 51-52]

In September 1952, on the initiative of the Central Committee of the Komsomol and the Ministry of Education of the Union Republics, a All-Union Meeting on Extracurricular and Out-of-School Education was held. The result of the meeting was the resolution, which identified the main proposals: improving the quality of educational work, helping schools, Komsomol, pioneer organizations improve out-of-school and extracurricular work with children, coordinating extracurricular activities, and prospects for its further development. [14]

The rapid growth of the network of institutions of extracurricular education, the differentiation of the 
functions, the need to provide with skilled personnel, and the improvement of the quality of their work have led to the need for ordering the system and types of these institutions. The decision of the Council of Ministers of the USSR (1952) «On the ordering of the network, the introduction of standard states and the establishment of salaries for employees of out-of-school institutions») established a single nomenclature of institutions of extracurricular education, defined the legal status of their employees, outlined ways for further development of these institutions in the urban and rural areas. [2, p. 5]

The course to increase the network of institutions of extracurricular education in the city and the countryside, the involvement of clubs, houses, palaces of culture and other educational institutions in educational work with children was also laid down in the VI Five-Year Plan for the Development of the National Economy in 1956-1960. $[9, \mathrm{p} .46]$

A significant role in improving the activities of institutions of extracurricular education was made by the Law «On the Strengthening of the Studs' Layouts with Life and on the Further Development of the National Education System in the USSR», adopted on December 24 , 1958. In 1959, a similar law was adopted in the Ukrainian SSR. These laws became the basis for improving the content, forms and methods of extracurricular education. [9, p. 53-61]

In the previously mentioned normative-legal documents, the need for the development of a very diverse personality, the cultivation of her creative abilities and potential was noted. Therefore, along with the most massive at that time, the directions of out-of-school education, technical and ecological-naturalistic, other areas begin to develop intensively, including tourist-local lore studies. The following normative documents lay the foundations for improving and diversifying of the forms of work with children.

If the first stage is characterized by the increasing the number of institutions of extracurricular education, then at the beginning of the second stage, we observe the growth of the institutions of the out-of-school education themselves (the number of pedagogical workers, circles, children's coverage, etc.).

The beginning of a new second stage of the formation of a legal and regulatory framework for institutions of extracurricular education (1973-1991) outlined the AllUnion Law of July 19, 1973, «Fundamentals of the Legislation of the Union of Soviet Socialist Republics and the Union Republics on People's Education».

Article 5 «Fundamentals of Legislation» defined «extracurricular education» as one of the components of public education. Section VIII of the Law is entirely devoted to extracurricular education and the upbringing of children. The purpose of the creation and development of a network of institutions of extracurricular education in the USSR in accordance with Article 51 of the Law is the development of children's interests and abilities, the implantation of skills in social and labor work, vocational guidance, education, autonomy, interest in science, literature, technology, art, military patriotic education. , providing meaningful leisure and recreation, smoking and strengthening the health of children and young people. [3]
The Ukrainian version of the «Fundamentals of the legislation of the USSR and the Union republics about the people's education» appeared later with the adoption of the Law of the USSR «National education» of October 1, 1974. [7]

During this stage the process of differentiating the interests of children was reflected in the creation of a wide network of specialized institutions of extracurricular education, the main task of which was to ensure the development of children's creative abilities in one or another field of knowledge, to promote self-realization in accordance with their individual needs.

However, the second stage is characterised by mass of the phenomenon of extracurricular education. The network was constantly expanding and in order to avoid absorbing quality by the quantity it required a certain structuring and ordering. To that effect, the Council of Ministers of the USSR issues a resolution «On the nomenclature and the procedure for institutions of extracurricular education», which provides for creating an accurate list of out-of-school institutions as of January 1976. As a result of this work, such a list was approved by the Ministry of Education of the USSR on January 12, 1976, and it contained 12 types of institutions of extracurricular education (houses and palaces of pioneers, young tourists 'stations, naturalists, technicians, pupils' rooms, children's and youth sports schools, children's youth clubs of young sailors, palaces of culture, children's parks, libraries and camps, stadiums, art and music schools. children's choir studios have added to the list. [1, p. 228]

Indeed, the tourist-local lore direction of out-of-school education (instructional, methodological, organizational and mass work, circular work) was regulated by the «Regulation on Republican, Regional, Regional, District Youth Tours (approved by the Ministry of Education of the USSR on January 19, 1977). [1, p. 244-248]

Contrary to the optimistic statistical data of the rapid development of the system of out-of-school education in the 70's of the twentieth century, the main disadvantage was excessive politicization, which was reflected mainly on the content of its implementation. Another problem of the whole system of public education of the Ukrainian SSR during the first and second stages was the lack of skilled personnel who could support it during the rapid development and expansion of the network.

In the early 80 's, the course was taken to fundamental reevaluation of the teacher training system for work in the institutions of extracurricular education. Thus, on October 31,1980 , the resolution of the Council of Ministers of the USSR on the enhancement of tourist-local lore activity in the country was issued through the establishment of interaction between state authorities, local selfgovernment and public organizations. [10, p. 140]

Against the backdrop of crisis phenomena that were brewing in various spheres of the state's vital activity, the permanent struggle of central authorities with opposition movements was the issue of the development of the education system, the more institutions of extracurricular education were no longer on the agenda.

And even after the adoption of the resolution by the Verkhovna Rada of the USSR on April 12, 1984, «On the main directions of the reform of the general and 
vocational schools» did not significantly change the situation. The document was declarative and did not correspond to the realities of the political confrontation that swept the country.

The processes of systemic disintegration that took place in the late 1980s in the society, the political system, and the national economy of the USSR led to the cessation of its existence on December 26, 1991. Instead, new independent states, including Ukraine, appeared on the political map of the world.

Thus, during the second stage, the process of systematization and streamlining of the network of institutions of extracurricular education, the work of which has now been defined by standard regulations and other normative documents, continues. In the background of the economic and political crisis at the end of the second stage, we state the manifestations of the stagnation of the system of out-of-school education, its gradual deideologization.

The beginning of the third stage was the Law of Ukraine «Education», adopted on the dawn of independence of Ukraine on May 23, 1991, which consolidated the directions of reforming the Ukrainian legal and regulatory base of out-of-school education, clearing it from Soviet dogmas and principles.

Article 38 of the Law defines extracurricular education in Ukraine as a part of the structure of education, which is responsible for the level of development of abilities, inclinations, talents of children, pupils, students. Also, institutions of extracurricular education are tasked with meeting the interests, demands and needs of the professional development of the younger generation on the principles of voluntarism, transparency and democracy. [5]

An important document in this group is the resolution of the Cabinet of Ministers of Ukraine «About the State National Program «Education» («Ukraine XXI Century»)» of November 3, 1993, in which the priority strategic task of extracurricular education and upbringing was to determine the creation of conditions for obtaining additional education for children through their participation in various activities, including tourist-local lore direction. [11]

In accordance with the «Measures to implement the State National Program «Education» («Ukraine XXI Century»)», in 1993, the Ministry of Education of Ukraine and the Institute for System Research of Education developed a «Concept of the main directions of development and renewal of the activities of institutions of extracurricular education of Ukraine», which defined the basic tasks and guidelines for the development of the organizational structure, the updating of the content of extracurricular education and historical and local lore work in institutions of extracurricular education in the early 90's. [8]

In accordance with the Concept, a «Regulations on an Out-of-School Educational Institution» was approved, approved by the Cabinet of Ministers of Ukraine on January 26, 1994. [13]

It should be noted that in the early 90 's of the twentieth century the system of education in general, and the system of extracurricular education in particular, were in a state that did not meet the needs of the newly created state, the transformation of various spheres of public life. This was mainly reflected in the discrepancy between the level and peculiarities of contemporary education with individual inquiries, social challenges and world trends.

The current state of the normative-legal base of institutions of extracurricular education of tourist-local lore direction is determined by the permanent process of updating this system, bringing it in accordance with the world standards of education. So, let's consider the main components of the system of normative-legal support of historical and local lore work in institutions of extracurricular education of the fourth stage.

The last stage of updating the legal base of institutions of extracurricular education begins with the adoption of the Law of Ukraine «Out-of-School Education» on June 22, 2000. This legislative act consolidated the status of extracurricular education, outlined its structure and organizational principles. [6]

The latest Education Act, which reflects the latest trends in the development of this industry, is the Law of Ukraine «About Education» of September 5, 2017, where the article 10 defines out-of-school education as one of the components of education in Ukraine. The law clearly defines the purpose of out-of-school education as a development of children's and youth's abilities in the fields of education, culture, science, physical culture and sports, obtaining the initial professional competences required for socialization, self-realization and professional development. [4]

In a separate group of normative legal documents refer the resolutions of the Cabinet of Ministers of Ukraine. Today are relevant and those that create conditions for the functioning of institutions of extracurricular education of the resolution «The approval of the list of types of out-ofschool educational institutions and the Regulations on the out-of-school educational institution», «Improving the organization of work on the education of children and young people in extracurricular educational institutions», «About the approval a plan of measures to increase the level of patriotic education of students and students through the systematic thematic excursions with the visit of objects ulturnoyi heritage», "The approval of study in the period up to 2010» and so on.

It is in the «Regulation on the Extracurricular Educational Institutions») (Resolution of the Cabinet of Ministers of Ukraine dated May 6, 2001) a comprehensive list of specialized institutions of extracurricular education of the tourist-local lore direction is prescribed: «Centers, houses, clubs, tourism bureau, local lore studies, sports and excursions of student youth, tourist-local lore creativity of student youth, station of young tourists». [12]

The next group of normative legal documents, we distinguish the Decrees of the President of Ukraine, which consolidate the main strategic directions of development and reform of the sphere of extracurricular education.

Thus, conceptual ideas and views on the development of out-of-school education are reflected in the Decrees of the President of Ukraine «The National Doctrine of the Development of Ukraine's Education in the 21st Century», «The National Strategy for the Development of Education in Ukraine until 2021», «Measures to Ensure the Priority Development of Education in Ukraine» and 
«Measures for the Development of the System for the Detection and Support of Gifted and Talented Children and Youth», «Measures to Support the Local Lore Movement in Ukraine», etc.

Conclusions and prospects of further scientific research in this direction. In this scientific research, we highlighted the normative and legal documents that outline the conceptual directions, structural and organizational principles, means, forms, and other aspects of the historical and local lore work of institutions of extracurricular education in the tourist-local lore direction of the second half of the XXth - the beginning of the XXI century. The process of their continuous updating in accordance with current challenges and inquiries in the educational environment continues to this day.

Therefore, it is quite logical to further improve the regulatory base in this area and this process must take place in a comprehensive manner, through the coherence of the actions of all its subjects. Separately, a mechanism for interaction between state authorities and civil society institutions in the field of historical and local lore work with children and out-of-school education services is required.

\section{ЛІТЕРАТУРА}

1. Внешкольное образование / под. ред. Л.К.Балясной. Москва : Просвещение, 1978. - 256 с.

2. Вопросы внеклассной и внешкольной работы с детьми: Сборник статей / Упр. школ М-ва просвещения РСФСР. Москва : Учпедгиз, 1955. - 232 с.

3. Закон СРСР «Основы законодательства союза ССР и союзных республик о народном образовании» от 19.07.1973 p. [Електронний ресурс]. - Режим доступу : http://www.economics.kiev.ua/download/ZakonySSSR/data0 3/tex14639.htm

4. Закон України «Про освіту» від 05.09.2017 р. № 2145-VIII. [Електронний ресурс]. - Режим доступу https://zakon.rada.gov.ua/laws/show/2145-19

5. Закон України «Про освіту» від 23.05.1991 р. № 1060-XII. [Електронний ресурс]. - Режим доступу https://zakon.rada.gov.ua/laws/show/1060-12

6. Закон України «Про позашкільну освіту». 2000 р. Позашкільна освіта в Україні : нормативно-правове регулювання : в 2 т. - Київ : Форум, 2009. - Т.1. - С. 59-84

7. Закон УРСР «Про народну освіту» від 01.10.1974 р. [Електронний ресурс]. - Режим доступу http://search.ligazakon.ua/l_doc2.nsf/link1/T742778.html

8. Концепція основних напрямків розвитку та оновлення діяльності позашкільних закладів України. - Київ : Освіта, 1993. $-47 \mathrm{c}$.
9. Народное образование в СССР : Общеобразоват. школа : Сборник документов 1917-1973 гг. - Москва : Педагогика, 1974. - 559 с.

10. Народное образование в СССР : сб. нормат. актов / [сост. Н.Е. Голубева]. - Москва : Юрид. лит., 1987. - 333 с.

11. Постанова Кабінету Міністрів України «Про Державну національну програму «Освіта» («Україна ХХІ століття»)» від 03.11.1993 р. [Електронний ресурс]. - Режим доступу : https://zakon.rada.gov.ua/laws/show/896-93$\% \mathrm{D} 0 \% \mathrm{BF}$

12. Постанова Кабінету Міністрів України «Про затвердження переліку типів позашкільних навчальних закладів і Положення про позашкільний навчальний заклад» від 06.05.2001 p. № 433. [Електронний ресурс]. - Режим доступу : https://zakon2.rada.gov.ua/laws/show/433-2001$\% \mathrm{D} 0 \% \mathrm{BF}$

13. Постанова Кабінету Міністрів України «Про затвердження Положення про позашкільний навчальновиховний заклад» від 26.01.94 р. № 45. [Електронний ресурс]. - $\quad$ Режим доступу https://zakon.rada.gov.ua/laws/show/45-94-\%D0\%BF

14. Резолюция Всероссийского совещания по вопросам внеклассной и внешкольной работы с детьми. 10-14 сент. 1952 г. / Упр. школ М-ва просвещения РСФСР. - Москва : Учпедгиз, 1953.-15 с.

\section{REFERENCES}

1. Out-of-school education / under. edit L.K.Balyasnoy. - 9. National education in the USSR: general education school : Moscow : Enlightenment, 1978. - $256 \mathrm{p}$.

2. Issues of out-of-school and extracurricular work with children : collection of articles / Department of Schools of the Ministry of Education of the RSFSR. - Moscow : Uchpedgiz, 1955. $-232 \mathrm{p}$.

3. The USSR Law «Fundamentals of the Legislation of the Union of the SSR and the Union Republics about National Education» dated 19.07.1973 [Electronic resource]. - Access mode

http://www.economics.kiev.ua/download/ZakonySSSR/data0 3/tex14639.htm

4. The Law of Ukraine «Education» dated 05.09.2017 No. 2145VIII. [Electronic resource]. - Access mode : https://zakon.rada.gov.ua/laws/show/2145-19

5. The Law of Ukraine «Education» dated 23.05.1991 No. 1060XII. [Electronic resource]. - Access mode https://zakon.rada.gov.ua/laws/show/1060-12

6. The Law of Ukraine «Extracurricular Education». 2000. Outof-school education in Ukraine : legal regulation : in $2 \mathrm{t}$. Kyiv : Forum, 2009. - T.1. - P. 59-84.

7. Law of the USSR «About National Education» dated 01.10.1974 [Electronic resource]. - Access mode : http://search.ligazakon.ua/1_doc2.nsf/link1/T742778.html

8. Concept of main directions of development and updating of activity of out-of-school establishments of Ukraine. - Kyiv : Education, 1993. -47 p. collection of documents from 1917-1973. - Moscow : Pedagogics, 1974. - $559 \mathrm{p}$.

10. National education in the USSR : collection normal acts / [cons. NOT. Golubeva]. - Moscow : Yurid. Lit., 1987. - 333 p.

11. Resolution of the Cabinet of Ministers of Ukraine «State National Program «Education» («Ukraine XXI Century»)» of 03.11.1993 [Electronic resource]. - Access mode : https://zakon.rada.gov.ua/laws/show/896-93-\%D0\%BF

12. Resolution of the Cabinet of Ministers of Ukraine «On approval of the list of types of out-of-school educational institutions and the Regulation on the out-of-school educational institution» of 06.05.2001 No. 433. [Electronic resource]. - $\quad$ Access mode https://zakon2.rada.gov.ua/laws/show/433-2001-\%D0\%BF

13. Resolution of the Cabinet of Ministers of Ukraine «Approval of the Regulation on the out-of-school educational institution» dated 26.01.94 No. 45. [Electronic resource]. Access mode : https://zakon.rada.gov.ua/laws/show/45-94$\% \mathrm{D} 0 \% \mathrm{BF}$

14. Resolution of the All-Russian meeting on out-of-school and extracurricular activities with children. September 10-14 1952 / Department of Schools of the Ministry of Education of the RSFSR. - Moscow : Uchpedgiz, 1953. - 15 p. 